\title{
Adikmas Role Through Unit Dikyasa Figures In Pressing Traffic Violations By Senior High School Student In Jurisdiction Area Of Polres Rembang
}

\begin{abstract}
Dadik Purnomo ${ }^{1}$
Abstract. The title of this research is the Dikmas role through dikyasa units in suppressing the number of traffic violations by high school students in the Police Law Rembang. This study aims to the extent of the role played by Dikyasa Unit Police Traffic Unit in providing Dikmas Then Especially to students. This study uses the concept and theory as a knife analysis, which uses the concept of optimization, Dikmaslantas concept, the concept of prevention, the concept of traffic violations, the concept of students, operant conditioning theory, management theory, communication theory, and the theory of social control. With the conclusion of the implementation of Dikmas then still not optimal due to the persistence found the factors inhibiting the implementation of Dikmas So like; factors personnel, budgetary factors, factors of infrastructure, and the target location Dikmas factors that are difficult to reach. Therefore, all the inhibiting factors must be anticipated that the implementation of the activities can be carried out Dikmas necessarily optimal in reducing the number of traffic violations by high school students.

Keywords: Dikmas; Traffic Violations; Dikyasa Unit; Senior High School Student.
\end{abstract}

\section{Introduction}

Violations of traffic on the highway is one result of disorderliness traffic by road users. Disorderliness traffic on the highway by road users is the onset of other traffic problems. These problems if allowed to continue it will potentially cause a greater impact that traffic violations such as traffic congestion and traffic accidents. Therefore traffic prosecuted Force role in addressing the problems of the current traffic as was the case at the police station jurisdiction.

Regency is one of the districts in Central Java province. Administratively Rembang consists of 14 districts, 287 Village / Village, with a population of 628579 inhabitants. Rembang is one district that the rate of accidents especially Traffic on the highway is very worrying. This is because one of the main access Rembang is the northern Pantura.

Traffic violations generally often performed by high school students in Indonesia and the whole of them are teenagers who are in transition to adulthood, teenagers have a very unstable condition in terms of emotional and psychological. Behavior will be strongly influenced by interactions among peers, neighborhood, and pattern formation is applied in the environment. Traffic violations by high school students are often made on the basis of intent because of his need for recognition that high school students who committed the offense is considered a great and when to do things that are forbidden by the applicable rules, especially rules about traffic.

One effort in conducting preventive Police through Dikmas then carried out by the Police traffic unit. Dikmas then is any activity that includes all efforts to foster

\footnotetext{
${ }^{1}$ Students of Masters (S2) of Law Faculty of Law Unissula Semarang email: dadikpurnomo31@gmail.com
} 
understanding, support and active community involvement in the quest for security, safety, order and smooth traffic. As the program is expected Dikmas then, can raise awareness and pasrtisipasi community, especially high school students in the jurisdiction of Police Rembang to always orderly in traffic for the realization of security, safety, order and smoothness in traffic.

To optimize the Dikmas, needs to be done approach to public figures, such as youth leaders, religious leaders, so that they can become a partner of the National Police to be pioneers in their environment each creating a situation Kamseltibcar So, as do the admonition to people in their environment who violate the rules ago cross. Where during the period of 2015 through 2016, there were 901. Of that number, which as many as 220 people died, 14 people were seriously injured and slightly injured 1,143 people.

This study aimed toknow the general idea of cross traffic violation by a student that occurred in the police station jurisdiction; To find out what are the efforts made by the Unit Dikyasa Traffic Police Unit in providing Dikmas Then to students; To determine the factors that become obstacles in the implementation of tasks in providing Dikmas dikyasa unit then.

\section{Research Methods}

The approach used is a qualitative approach. This approach is directed at the individual background and holistic (whole). So, in this case should not isolate individual or organization into a variable or hypothesis, but it needs to be looked at as part of a wholeness (Moeloeng, 1998: 3). As for the nature of this research is descriptive. Descriptive method can be interpreted as a troubleshooting procedure investigated by depicting or describing the state of the research subject or object (person, institution, community, etc.) at the present time based on the facts that appear or as it is. Data collected in the form of words, pictures, and not numbers. Such data may be derived from the text of the interview, court records, photographs, videotapes, personal documents,

While the approach is one approach shot approach. That is an approach to research done by using one collection of data on the "one time". According Suharsini Arikunto (2006: 83), that an investigation can be conducted using one approach shot approach. That is, that the approach in the research carried out by someone based on one collection of data on the "one time".

The kind of research can enter the descriptive study. "Qualitative descriptive study, means that the research method used in this study is a qualitative research method. By interview, observation and review of documents. Where in data reporting and analysis of the problem is shown in the form of words, pictures, video and or numbers without calculation management data using statistical formulas. (Moleong, 2004: 9). "The reason for using this qualitative research because the research is to understand the phenomenon of what is experienced by the subject of the study such as behavior, perception, motivation, action by way of description in the form of words and language, in a specific context natural and by using various natural methods.

\section{Results And Discussion}


The data from the Traffic Police Unit number of traffic accidents decreased dibangdingkan territory is happening in other areas, until the month of August 2018 a total of 259 events. Then the interview with Police, Adj AKP ROY IRAWAN, SH, MH said there was a decrease for the fatality rate on the victim, this figure because there is an increase in the vehicle.

The decline in the fatality rate in the widely influential enough victims, for example victims are the backbone of the family certainly can not support a family if a fatal accident. Likewise relatives or relatives certainly going to feel the loss. Police Traffic Unit continues to conduct preventive patrols and take actions in a measurable, as well as to socialize regularly and periodically, especially for high school Plajar throughout the District.

Then Police Chief Unit Adj through Iptu Dikyasa Ngainul Mujib, SH said that information dissemination regularly and periodically on high school students throughout the district to provide an understanding of the activities of the students to orderly in traffic. How that is done is citedway traffic / berkendarayang well according to the rules. Additionally, emphasized to the students to complete the vehicle should be standard for safety. appeal is also provided to improve discipline yourself either at home, school, let alone on the highway is very important because of the discipline and orderly berlalulintas is one of the efforts to prevent traffic accidents. Traffic is good and right and obey traffic rules, obey the signs - traffic signs and road markings, because accidents do not see much nearby our destination, be careful on the road so safely reach the goal.

The results of the findings include social factors, as well as in an interview given to the Resort Police, Adj AKP Roy Irawan, $\mathrm{SH}, \mathrm{MH}$ in space Kanit Dikyasa in an interview said: Most of the violators of traffic among students in the area of law Police Rembang is the high school students who are members of the motorcycle community moving in a negative direction or commonly known motorcycle gang where students who are members of these communities tend to not care about traffic rules there is, therefore Dikyasa unit through Dikmas then tried to take action with a touch and raising of the motorcycle community which had a negative connotation that the members of the community easier to navigate in orderly traffic.

From the interview above, the researcher explains that students who are members of the motorcycle community to the negative ones such as motorcycle gangs tend to feel himself great if the community has managed to do a traffic violation and became the center of public attention, and they tend to commit physical violence against fellow community another motor and society, It happened because of the emotions of the students are still somewhat unstable and their desire for recognition of other motorcycle community or fellow members in the same community.

Entry in the motorcycle community has a special meaning for students who are still teenagers where they can add friends and share the fun or hobbies they like modification of the motor to just inner satisfaction received. In addition to joining in the motorcycle community of students feel they can spare time for a refreshing shake the fatigue they experience after after school.

As explained previously, the need for recognition of other communities too often encourage intentions and behavior of students who are members of the community 
the motor is to compete in a way that may disturb security and order in society in general as well as activities that disturb the security, safety, order and smoothness (Kamseltibcar) in cross elapsed.

But keep in mind that students are the future generation and must be supervised in the mix because if wrong in the mix can ruin their future is still a long process in achieving their goals. In this respect the role of parents is very necessary to control or supervision by pro-active with their children to prevent juvenile delinquency that could damage their children's future. As a small example is a traffic violation, by allowing children under the age of riding a motorcycle synonymous with impunity juvenile delinquency committed by her son apart for any reason because in orderly traffic has been regulated.

The second is related to the high school distance factor wishes of parents and the child's interest to obtain a quality education to make people (parents) who were in the village as well as in the district strives to send their children to a favorite school in the center of the county. The majority of parents do not matter how far the distance covered by his son in order to go to a school that is a favorite and accredited well although there are also some parents who choose to allow these children to stay in a place like boarding-kos's that close to the location school than having to commute every day.

Besides, there are some parents did not allow her to stay outside the house as a boarding-kos's because of several factors: the association of children that can not be controlled entirely by the parents, if living outside the home, as well as the susceptibility of fraud occurs especially students are children who are still minors, as well as the unreadiness parents to split up residence with his son because of the nostalgia of the children who sometimes often arise as a result of a strong bond between parent and child.

For the effectiveness and efficiency of time and material (money) then students opt for riding a motorcycle instead of using public transportation or stay at a boarding school located nearby. On the basis of the same reason parents tend to let their children drive a vehicle like a motorcycle to school even though they know that their children do not have the completeness of the drive and did not even wear safety gear in driving.

The efforts made by the Apex Police Dikyasa unit reduces lift traffic violations among high school students is as follows:

First, approach educative conducted by the unit Dikayasa Traffic Police Rembang is the form of activities of the traffic safety campaign in schools performed at the ceremony to provide knowledge and understanding to students about traffic, the implementation of the extension to school school by providing material about traffic rules, traffic violations, traffic safety and traffic rules and goes to school police activities which provide materials on traffic to schools continuously in order to change the mind set or behavior of students in traffic. Activities carried out every 3 (three) times a week by giving every time a different material and given games-games interesting to get a gift from Dikmas officer. Last educational efforts conducted by the Traffic Police Dikyasa unit Rembang is riding safety activities which in practice is done by direct practical use vehicle. In the provision of material safety riding activities highly 
in demand by high school students for their implementation through direct practice and matter of orderly traffic and traffic safety is more easily understood by students.

SecondApproach through coaching is meant here is the direct coaching conducted by the Traffic Police to Saka Then Bhayangkara Krida and School Safety Patrol which aims to assist the police, especially in the field of traffic.

Third, Socio-Cultural Approach is an activity performed by the Traffic Police Rembang to do fundraising to the motorcycle community in Rembang district police jurisdiction to obey the rules and prioritize safety in road traffic.

FourthEfforts Apex Police traffic unit to prevent traffic violations not only of the preventive approach, in educational, training, and socio-cultural approach, but also repressive approach by providing a sympathetic strikes and repression of traffic violations. In a sympathetic strike action by giving a reprimand and a warning is sympathetic to the traffic violators who deliberately melakukakan offense. In the execution personnel Apex Police traffic unit can be friendly and not arrogant when admonish motorists in traffic. When you find the motorists who violate the clerk politely give a warning and an understanding that the perpetrators of traffic offenses, not to repeat perbuatanya because it could jeopardize the safety of motorists traffic. In other words, in the implementation of measures repesif was still no action preemptive, after the rider was given a reprimand sympathetic and still found violations of subsequent re personnel unit of the traffic police station Rembang give warning evidence of violations to motorists who violate order to provide a deterrent effect for penegendara and reduce violations traffic in Rembang district police jurisdiction, so that their efforts can affect the realization of security, order,

Factors that hinder the implementation of Dikmas Then in the jurisdiction of Police Rembang is as following:

- Personnel factors

The lack of personnel in the unit Dikyasa greatly hamper Apex Police Unit in providing the materials Dikmas Dikyasa Then the high school students. Limitations jumlanh members who served in the Traffic Police Unit Dikyasa Rembang is affecting.

- Budget factors

Then Dikmas activities to school and riding safety activities only in tanggungsebanyak six times in a year of activities and to fund activities targeting Then Dikmas transport drivers only in responsibility activities four times a year. Budget funds available must be very less when compared to the target area of Dikmas necessarily based Rembang police station jurisdiction.

- Infrastructures factors

Apex Dikyasa Traffic Police Unit are still constrained in terms of infrastructure. The lack of supporting facilities such as projectors, laptops, vehicle type which can not browse remote area Rembang make frequent delays Dikmas activities So especially when going sambang school to school. For laptops and projectors are only available each unit and sometimes often used for other activities of Satlantas which can certainly inhibit the activity Dikmas So to schools.

- Then the target location factor Dikmas 
Rembang regency territory consists largely of mountains and hills. This is an obstacle for the Traffic Police unit Rembang Dikyasa difficult to reach a distant target in rural areas, especially in mountainous and hilly areas in providing the materials Dikmas so to the people in the jurisdiction of Police Station evenly memalui Rembang police program goes to the village. Bad weather replenish the difficulty of the target to be in use, such as the rainy season which can lead to flooding and landslides. State of the weather and the terrain became a problem that until now has not been able to be resolved, especially vehicles that are not allowed to enter the rural areas whose location is hard to reach.

\section{Closing}

\subsection{Conclusion}

- Traffic violations are most often carried out among students, especially high school students is not have a driving license, was not wearing a helmet Indonesian National Standard (SNI), do not use the rearview mirror, the tire is not standard, exhaust Brong, the plate does not match the vehicle registration and others.

- Efforts Dikmas Unit Dikyasa Apex Police Traffic Unit in preventing traffic violations not only of the preventive approach, in educational, training, and socio-cultural approach, but also repressive approach by providing a sympathetic strikes and repression of traffic violations.

- Factors that become an obstacle in the implementation of Dikyasa Unit task in providing such factors Dikmas Then Personnel, Angaaran Infrastructures and areas where it has become difficult to be reached by the Personnel Unit Dikmas Dikyasa Apex Police Traffic Unit.

\subsection{Suggestion}

The research results are as previously described, that Dikmas then carried out by the Police Unitdikyasa Rembang in efforts to reduce traffic violations among high school students has not been optimal. Therefore, the researchers propose some suggestions to be used as input and evaluation materials to optimize the results to be achieved Dikyasa Traffic Police unit Rembang through Dikmas Then the following efforts:

- Police Chief Rembang should instruct the police station, and ranks in order to coordinate with schools to explain to parents that their decision to let their children bring a motor vehicle action is not appropriate because minors are prohibited by the Act for driving a vehicle and can lead to accidents traffic. Provide guidance on legal awareness to the high school students in order to motor vehicle traffic violations by the high school students can be minimized.

- In law enforcement on the high school students should be focused to give warning and educating high school students who are found not orderly and violating traffic rules, for example by visiting schools to conduct direct inspection of the vehicle high school students as well as checking the completeness of the letters driving and traffic safety equipment such as helmets. 
- Improving the ability of workers Dikmas So that is a member Dikyasa Traffic Police Rembang in terms of procedures for delivery of materials with effective communication in accordance with the theory of communication that has been discussed by researchers in the previous chapter for the messages Kamseltibcar So well received by high school students. This is done by incorporating vocational education for vocational education belummendapat personnel.

- He adds infrastructure such as props, projectors and others to maximize traffic personnel in providing the materials Dikmas then to students. Because of all this in providing the materials Dikmas then always use inventory items schools.

- In the case of transport used to support the performance of Dikmas So to schools in remote areas in accordance with the program Dikmas So the latest police goes to the village the researchers suggested that the need for the vehicle on the unit Dikyasa Traffic Police Rembang adjusted by field target location Dikmas then that difficult to pass. Researchers suggest Dikyasa Police Unit in order to do the procurement of vehicles Rembang R-4 of type double axle danpengadaan R-2 is capable of passing through rough terrain.

- Creating a mobile SIM program goes to school, which works together with the Traffic Police Regident unit Rembang in providing facilities and services for high school students who want to make the SIM as a condition for the legitimacy of the police in driving. In addition to more effective and efficient, mobile SIM program goes to school is expected to help the high school students in order not to miss class because the students obtaining a driving license are increasingly asking for permission to the school resulting in students miss class at school.

- Collecting data on the motorcycle community activism is good and not good to anticipate. Working together with the FT. Sabhara in the motorcycle community activism collection is not good in a way to find information and perform data collection on the motorcycle community members were caught by members of Sabhara when on patrol. Then do fundraising to the motorcycle community that has been recorded that in any events and activities carried out can be monitored as efforts to prevent the threat of disruption either crimes of a criminal nature or behavior that violates the discipline of driving such as illegal racing and others.

- Cooperate with the FT. Binmas in providing information to the public to be around as much as possible every parents do not allow their children to drive a motor vehicle before the child has a driver's license as proof of the legitimacy of the police that the child already has competence in bekendara. Then make known to all parents to remind their children to orderly traffic, giving priority to the safety of themselves and others in order to avoid the things that does not want such as traffic accidents because children still have a future to be able to achieve.

\section{Bibliography}

[1] Lexy J. Moeloeng 2010. Metodologi Penelitian Kualitatif edisi revisi cet. 27 Bandung: Remaja Rosdakarya.

[2] M. Djunaidi Ghoni dan Fauzan Almanshur 2012.Metodologi Penelitian Kualitatif cet. 1 Jogjakarta: Ar-Ruzz Media. 
[3] Suharso dan Ana Retnoningsih 2011. Kamus Besar Bahasa Indonesia edisi lux cet. 9 Semarang: Widya Karya.

[4] George R. Terry dan Leslie W. Rue 2014.Dasar-Dasar Manajemen cet 15 Jakarta: Bumi Aksara.

[5] Suharsimi Arikunto 1998. Prosedur Penelitian Jakarta: Rineka Cipta.

[6] Arikunto Suharsimi. 1999. Prosedur Penelitian Suatu Pendekatan Praktek Jakarta: PT.Rineka Cipta.

[7] Creswell John W. 2014. Reasearch Design Pendekatan Kualitatif Kuantitatif dan Mixed. Yogyakarta: Pustaka Pelajar.

[8] Littlejohn S. W. dan Foss Karen A. 2014.Teori Komunikasi. Jakarta: Salemba Humanika.

[9] Daryanto dan Muljo Rahardjo. 2016. Teori Komunikasi. Yogyakarta: Gava Media.

[10] Mulyana Deddy. 2009. IImu Komunikasi Suatu Pengantar cet 14,Bandung: Remaja Rosdakarya

[11] Act No. 08 Year 1981 About the Code of Criminal Procedure

[12] Act No. 2 of 2002 on the Indonesian National Police

[13] Act No. 22 of 2009 regarding Traffic and Road Transportation

[14] Police Regulation No. 15 of 2013 on the Procedures for Handling Laka

[15] https://www.scribd.com/doc/229769814/PENGERTIAN-LAKA-LANTAS-docx

[16] Ops Zebra Candi 2017 : Sat Lantas Polres Ajak Pelajar Tertib Berlalu Lintas URL: https://humas.polri.go.id/2017/11/ops-zebra-candi-2017-sat-lantas-polres--ajakpelajar-tertib-berlalu-lintas.

[17] http://jlokowor.blogspot.co.id/2013/05/konsep-definisi-dan-penjelasanlengkap.html

[18] https://www.murianews.com/2016/12/30/104321/123-orang-meninggal-dalamkecelakaan-di-rembang.html 